\title{
Clinic in Crisis Response: Imagined Immunities
}

\author{
Peter Redfield ${ }^{1}$
}

Published online: 26 April 2016

(C) Springer Science+Business Media New York 2016

Military forces have long targeted medical facilities. In blog posts following the attack on the Médecins sans Frontières (MSF) hospital in Kunduz, Afghanistan, historians Bertrand Taithe and Eleanor Davey offer examples of parallel atrocities past and present, from German bombardment of Parisian hospitals in 1871 to recent attacks on MSF run facilities in Syria and Yemen. ${ }^{1}$ As their sobering list makes clear, legal protections have provided uncertain refuge in the years since the ink dried on the agreements of the initial Geneva Convention. Moreover, even this thin shelter has extended unequally, rarely including colonial confrontations. In his unconventional chronicle of death from the air, Sven Lindqvist (2000) underscores how laws of war effectively delimited perceived frontiers of civilization; Italian airplanes inaugurated aerial bombing in 1911 outside of Tripoli, and two decades later destroyed Red Cross Ambulances in Ethiopia. ${ }^{2}$ In Lindqvist's (2000:2) acid summary: "When is one allowed to wage war against savages and barbarians? Answer: always. What is permissible against savages and barbarians? Answer: anything."

\footnotetext{
${ }^{1}$ See posts by Bertrand Taithe "The Oldest War Crime in the Book" http://historyofhumanitarianaid. com/2015/10/05/the-oldest-war-crime-in-the-book/; and Eleanor Davey, "The Ashes of Kunduz" https:// aidhistory.wordpress.com/2016/01/21/the-ashes-of-kunduz/.

${ }^{2}$ Bernard Bridel, "Ethiopia 1935-36: mustard gas and attacks on the Red Cross" https://www.icrc.org/ eng/resources/documents/article/other/5ruhgm.htm.
}

Peter Redfield

redfield@unc.edu

1 Department of Anthropology, University of North Carolina at Chapel Hill, 306A Alumni Bldg., Chapel Hill, NC, USA 
The contributors to this special edition trace a similar line of perception and violation, that of medical neutrality and its ability to limit violence. To what extent can inhabitants of the clinic stand apart from conflict? Refreshingly, the authors approach this question from an ethnographic, rather than normative perspective, analyzing the range of what does happen instead of insisting on what should. The results are illuminating, if not always encouraging. As the editors note in their introduction, the shift from inter-state warfare to intra-state conflict exposes the latent force coiled within regimes as well as that between them. Any special status accorded to medical personnel depends on its recognition by others, a prospect that can prove distinctly tenuous in practice. The European refusal to apply the laws of war in colonial contexts reemerges within the body politic, appearing in police mistreatment of protestors, and the targeting of medics who help those opposed to the state. Both the language of civilization and the brutality it masked echo in the words of the Egyptian policeman who, asserting his superior authority, orders a physician to stop treating "thugs" (Bayoumi and Hamdy, this issue).

It would be tempting, then, to dismiss medical neutrality as a Potemkin norm, a pleasing façade to cover up a hollow legacy of failure. Or we might denounce it as a fetish, a misleading idol that promises false safety. However, the assembled cases suggest something more complex, a partial, possible enchantment sometimes productive even in its violation, an antipolitics with political possibilities. As documented by Soha Bayoumi and Sherine Hamdy, the efforts by some Egyptian doctors to assert their professional ethics may fail to contain state violence. The physicians involved may also overestimate the capacity of their profession to limit complicity_forgetting medicine's less savory episodes (e.g. Proctor 1988)_and overlook the everyday structural violence suffusing both national and global contexts. Nonetheless, their desire to pursue their calling and offer impartial care leads not to quiescence, but political engagement. Their disbelief that "international conventions" could be ignored and their white coats transformed into targets, whether or not politically realistic, inspires them with a sense of moral indignation. Neutrality here serves as a means, not an ends, and even a potential step on a road toward politicization.

The case of Izzeldin Abuelaish, presented by Guy Shalev, further underscores the potential productivity of claiming professional ethics amid conflict. As Shalev argues, Abuelaish's ability to present himself as a neutral, educated doctor, engaged in the humane work of offering medical care, allowed his personal suffering to become visible for segments of the Israeli public. The particularity of his storywhich as a reviewer points out would not be credible as fiction-emerges from the collective experience of conflict and suspicion, enabling him to appear as a reliable witness and voice of sanity. By speaking as a doctor he partially escapes classification among the threatening Palestinian mass, and can speak as a human. The result remains partial and limited; a moment of compassion in the theater remains unlikely to alter the larger political equation. Nonetheless, it does create the conditions for a certain critical translation of concern. Amidst political deadlock, the hospital can serve as a place where, as Abuelaish puts it, "humanity can be discovered." 
By contrast Emma Varley reminds us of hospital's potential to serve as a concentrated site of neglect and terror. Writing about sectarian violence in northern Pakistan, she illustrates how the logic of grouping a vulnerable population can expose people to injury as well as to care. Just as clinical spaces hold the constant threat of infection, so too they subject those within to the potential risk of violence, whether in the form of groups of armed militants or bombs from above. There are reasons to aim for hospitals, after all; along with other major structures and institutions, they offer significant targets by massing populations, as well as serving as a nexus of hopes and fears, the opposing edges of biopolitical imagination. In this way conflict raises the stakes for iatrogenic and nosocomial harm, the unintended damage caused by attempts to heal.

Clinical spaces, however, are not always contained or bound by walls. Can Aciksoz's description of violence surrounding protests in Istanbul widens the field of contest to include atmospheres, newly contaminated by the pervasive use of tear gas and other "nonlethal" approaches to crowd control like rubber bullets, water cannons, and beatings. By insisting that we include such techniques within any analysis of state violence, particularly the floating clouds of gas that material transform a given micro-environment, Aciksoz translates Peter Sloterdijk's analysis of trench warfare during the First World War into contemporary civilian contexts. The effects of this dispersed threat infiltrate and infuse the social atmosphere, inspiring a similarly dispersed mix of ironic graffiti slogans (e.g. "tear gas beautifies the skin") and efforts to assist those affected. Like the Egyptian doctors mentioned above, some Turkish health workers feel themselves called to act. They likewise ground their ethical imperative on humanitarian norms and a concept of emergency, and similarly find themselves targeted by the state. Here the response extends beyond the brute force and commands of individual policemen, into efforts to modify state law and even the Hippocratic oath itself. With crisis in the air, the Turkish government and its allies risk international condemnation to emphasize the primacy of state sovereignty and religious authority over professional ethics.

Lauren Carruth offers a more hopeful counterpoint on the theme of dispersed, mobile forms. Writing about clinical interactions in the Somali region of Ethiopia, her research foregrounds projects operating in the name of "global health diplomacy" rather than political suppression. She describes the failure of a local government clinic to inspire enthusiasm or trust in the surrounding community, and contrasts it with the relative success of a mobile team sponsored by UNICEF. Although both projects involve personnel marked as potentially untrustworthy outsiders, the members of the mobile team work to build interpersonal relationships. As a consequence they become preferred purveyors of health care, while fostering reconciliation in a conflict zone. Meanwhile the clinic's wards sit empty, belying its intended role as a regional health center. Ultimately, Carruth reminds us, clinical encounters are as much social as technical exchanges, involving a range of skills and evolving reputations. In post-conflict settings diplomacy becomes a profoundly immediate and personal affair; thus reconciliation begins at ground level.

Carruth's conclusion reflects the ethnographic tenor of this collection, resolutely focused on relations of practice. It also recalls the history of neutrality beyond medicine. As Stephen Neff (2000:7) observes in his historical survey of the topic, 
"[t]he law of neutrality, in short, was made not, as it were, from the top-down by scholars and commentators, but rather from the bottom-up by statesmen, generals, admirals and traders." Policies and principles might be drafted at a remove, but those who enact them do so in relation to each other, enforcing or exempting according to circumstance. From this perspective any state of neutrality is far from static: rather, as the editors of this edition stress, it involves continued cultivation and negotiation. However disappointing the results may prove-and the examples given here suggest frequent disappointment-the concept of medical neutrality proves enduringly productive. Its tensions and incompletions thus invite further investigation, focused less on an effort to perfect principles than on tracing their uncertain connection to particular social worlds.

Over three decades ago, Benedict Anderson pointed out how imagination serves as a lynchpin for the powerful attachment of nationalism, along with the violence it inspires (Anderson 1983). In recognizing the degree to which medical ethics too might depend on shared fictions, the contributors to this collection expand a parallel insight, highlighting the essential role of perception. Some aid world practitioners recently arrived at a similar, if differently inflected realization. A few years before the bombing of the hospital in Kunduz, MSF released the results of a multi-sited study of the views of those receiving the group's assistance (Abu-Sada 2012). The impetus for this venture stemmed from the organization's experience in settings like Afghanistan and Democratic Republic of Congo, where it struggled to differentiate itself from broader coalitions engaged in military as well as humanitarian ventures (the Swiss branch of MSF going so far as to paint some of its vehicles fuschia). As Michal Givoni (forthcoming) notes, this belated humanitarian interest in perception remains deeply instrumental and focused on management. Nonetheless, MSF's study offers an array of intriguing insights, both about the parameters of principles like neutrality and about the importance of specific relationships. Key details of the organization's structure and vision appear lost in translation, from its financial independence to its commitment to nonviolence. However, respondents displayed keen interest in the medical care provided, the degree it met their needs and the quality of engagement with local networks. If quick to interpret motivations within given cosmologies, they also remained open to particular experience. On such irregular ground, imaginative exchange seems an active, tenuous, yet ever vital work in progress. Decisions about whether or not to bomb might depend on no less.

\section{References}

Abu-Sada, Caroline, ed.

2012 In the Eyes of Others: How People in Crises Perceive Humanitarian Aid. New York: MSF, Humanitarian Outcomes and NYU Center on International Cooperation.

Anderson, Benedict

1983 Imagined Communities: Reflections on the Origins and Spread of Nationalism. London: Verso.

Givoni, Michal Forthcoming "Reluctant Cosmopolitanism: Perceptions Management and the Performance of Humanitarian Principles." Humanity: An International Journal of Human Rights, Humanitarianism and Development. 
Lindqvist, Sven

2000 A History of Bombing. New York: The New Press.

Neff, Stephen

2000 The Rights and Duties of Neutrals: A General History. Manchester: Manchester University Press. Proctor, Robert

1988 Racial Hygiene: Medicine Under the Nazis. Cambridge: Harvard University Press. 